\title{
Geography resources on the Internet
}

By Luigina Vileno

\section{Be a "virtual tourist" of planet Earth}

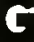

eographers study all living things and the earth features among which these creatures live. They are particularly interested in their location and distribution. Geographers look for spatial patterns and study how forces such as climate or human activity change the landscape. They use information from all clisciplines, including biology, demography, economics, geology, physics, and sociology

Because of the wide range of data of interest to geographers, practically all of the Internet could be useful in geographical studies. General geography sites as well as general directories such as Yahoo (access: http:/ www.yahoo.com) or the Argus Clearinghouse (access: http://www.clearinghouse.net) and search engines such as Lycos (access: http://www.lycos.com) or Alta Vista (access. http://altavista.digital.com) can be helpful.

Given the fluid nature of the discipline and of the Internet, the following is but a sampling of sites that were found to have some useful geographic information. Although this is clearly not a comprehensive guicle, I hope it will serve as a starting point for those who wish to use the Internet for geographical research.

\section{Geographical guides to the Web}

Virtual Tourist. A map-based clirectory of all the Web servers in the world. If one is interested in what Web resources are avalable in a particular country, one has only to click onto that spot on the world map and a list of sites is generated. Access: http://www.vtourist.com/.

\section{Starting points}

Human and physical geography

Geography World. Created by a geograpliy high school teacher, it is one of a few very good starting points. Its opening page has a table of contents with topics of interest to all geographers, for example: earth's surface and erosion, ecosystems and environmental issues, human culture, and maps and globes. Access: http://members.aol.com/bowermanl/101.html.

Nice Geography Sites. An extensive list of geographic information systems (GIS) and geography sites with strong European emphasis. A major drawback is that it is clivided into only three very broad categories: general geogra phy, GIS and remote sensing and geography and, GIS newsgroups. Access: http://www. frw ruu,nl/nicegeo.html.

University of Texas at Austin: Internet Resources for Geographers. This very "nice" site is a beautifully organized list of resources. Access: http://www.utexas.edu/depts/grg/ virtdept/resources/contents.htm.

University of Waterloo: Geography Subject Page. A Canádian example. Access: hutp: /www.lib.uwaterloo.ca/discipline/geog/ index.html

WWW Virtual Library: Subject Cata logue, Geography. Access: http://www icomos.org/WWW_VL_Geography.html.

Yahoo Geography Page. Access: http: www.yahoo.com/science/geography.

\section{Physical geograpby}

CSC Earth Science Server. The Center for Scientific Computing (CSC), a Finnish publisher, provides links to many areas in physical geography. Access: http://www.csc.fi/earth_science/ earth_science.html. 
Internet Resources in the Earth Sciences. A general directory site provided by the University of California at Berkeley's Library. It provides links to all areas of the earth sciences. Access: http://www lib.berkeley.edu./EAR'T FarthLinks.html

Landscape Ecology \& Biogeography. A list of sites in these two subject areas. Access: http://www.uni-sb.de/philfak/fb6/fr66/tpw geo-hot/anu_land.htm.

On-line Resources for Earth Scientists (ORES). Online resources available through the Internet and other networks that may be useful to those with an interest in the earth sciences. Access: http//www gisnet.com/gis/

Physical Geography Resources. A mixture of images, datasets, and data libraries of potential use to physical geographers. Access: http://feature.geography.wisc.eclu phys.htm.

\section{Gazetteers}

Geographic Nameserver. This server contains information mostly on locations in the U.S. Simply type in the name of a place and it will return with its telephone area code, latitude, longitude, population, elevation, and zip code. Access: http://www mit.edu:8001/geo.

National Imagery and Mapping Agency's (NIMA) GEOnet Names Server (GNS). A clattabase of foreign geographic feature names; 3.3 million features are updated monthly with names information approved by the U.S. Board on Geographic Names. You enter the name of a place and country and it returns with its designation, latitude, and longitude. Access: http: www.dma.gov/gns/html/index.html.

U.S. Gazetteer. A very useful tool, this gazetteer iclentifies places to view with the Tiger Map Server and oltains census data from the 1990 Census Lookup Server. One simply enters a place name. The server returns with population. location. and zip code information. It

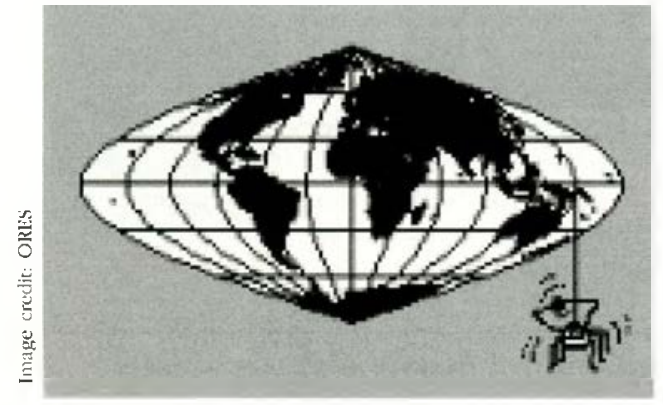

also links the user to a map of the area as well as census tables. For the tables, the user selects what variables should be displayed. $A C$ cess: http:/ www census gov/cgi-bin/gazetteer.

\section{Maps \\ United States}

Tiger Map Server (TMS). This project is sponsored by the U.S. Bureau of the Census. The goal is to provide a public resource for generating high-quality, detailed maps of anywhere in the United States using public geographic data. Access: http:/tiger.census.gov/

\section{Canada}

National Atlas Information Service (NAIS). A Canadian government site with base maps, geographical names, and thematic maps that "reflect the social, economic, environmental and cultural fabric of Canada." Access: http: WWW-NAIS.CCRS.NRCán.GC.CA

\section{Other}

MapQuest. A commercial site with a world atlas, trip planning, and routing information. Provides driving directions between U.S. cities. Interactive atlas lets you pinpoint places on the map. right down to the street. Access: http://www.mapquest.com.

Perry-Castañeda Library (PCL) Map Collection (University of Texas at Austin). Very useful and easy to use for anyone looking for maps. Inclucles links to electronic cartographic reference resources, electronic maps of current interest and of general interest worldwide, historical maps, and other map-related sites. $A C$ cess: http://www lib.utexas.edu/Libs/PCL/ Map_collection/Malp_collection.html. Ed. note: For a more extensive review of this site see the Internet Resources column on page 502.

3G on W3: The Great Globe Gallery. An interesting and fun collection of views of planet Earth. Includes illustrations of projections and thematic geological and environmental maps. Due to the heavily graphic material, loading takes some time. Access: http://hum.amu.edu.pl/ $\sim$ zbzw/glob/glob1.htm.

Xerox PARC Map Viewer. Accepts requests for a world or U.S. map and returns an html document including an image of the requested map. This is created on demand from a geographic database. One can zoom in on a selected point and generate another map. Access: http://pubwel).parc.xerox.com/mapdocs/ mapviewer.html. 
Satellite images and remote sensing United States

National Aeronautics and Space Administration (NASA). Includes many links to interesting information such as news items related to NASA; organization information; FAQs; and a page entitled "Mission to Planet Earthdedicated to understanding the many ways the Earth is constantly changing and how human beings influence those changes." Access: http: /www.nasa.gov/.

National Environmental Satellite, Data, and Information Service (NESDIS). Includes links to many departmental sites such as $\mathrm{Na}$ tional Geophysical Data Center; Office of Satellite Data Processing and Distribution; and the Global Environmental Disaster Monitoring (GEDM) Project. Access: http://ns.noaa.gov/ NESDIS/NESIDIS_Home.html.

SIR-C/X-SAR Images. A joint U.S.-GermanItalian project that uses a highly sophisticated imaging radar to capture images of Earth that are useful to scientists across a great range of disciplines. The image categories are: archaeology, cities, ecology \& agriculture, geology, interferometry, oceans, rivers, snow, ice, glaciers, and volcanoes. Access: http://www.jpl. nasa.gov/radar/sircxsar/.

\section{Canada}

Canada Centre for Remote Sensing (CCRS). Lots of information on CCRS, Canadian companies, and universities involved in remote sensing and remotely sensed images of Canada. Access: http://www.ccrs.nrcan.gc. ca/ccrs/ghomepge.html.

\section{Infernational regional information}

CIA World Factbook 1996. General handbook-type information on different countries, for example: flag and map, geography, people, government, economy, transportation, communication, and defense. Access: http://www. odci.gov/cia/publications/nsolo/wfb-all.htm.

City.Net. General and tourist information on 5,000 locations worldwide. Access: http:// www.city.net/

InfoNation. A United Nations site offering socioeconomic, demographic, and some environmental data. The environmental data include carbon dioxide emissions, forest area, and endangered species. Access: http://www.un.org/Pubs/Cyber SchoolBus/infonation.

International Data Base. Brought to us by the U.S. Census Bureau, this database contains demographic and socio-economic information for all countries of the world. Access: hetp:/ www.census.gov/ftp/pub/ipc/www/idbnew hitml.

\section{Statistical information United States}

Federal Geographic Data Committee (FGDC). A government site with links to various geospatial data sources: federal, state, university, foreign, commercial, and others. $A C$ cess: http://www.fgdc.gov/fgdc.html.

U.S. Census Bureau. The Home Page is organized around eleven functioning buttons: 1. News; 2. Access Tools; 3. Subjects A to Z; 4. Search; 5. CenStats - CenStore; 6. Just for Fun; 7. About the Census Bureau; 8. User Manual; 9. New on the Site; 10. Population Clock; and 11. Economic Clock. Access: http: /www.census.gov/

\section{Canada}

Statistics Canada. A wide variety of information on economic and social conditions in Canada. The basic subject divisions are: the land, the people, the economy, and the state. $A c$ cess: http://www.statcan.ca/.

\section{Weather and climare United States}

National Weather Service. Links to the latest U.S. weather information (warnings, forecasts, maps, and observations); climate statistics and historical archives; and information on hydrometeorology, the environment, geophysical tables, weather communications, standards

\section{Feature your collection on the cover of C\&RL News}

CERL Neus wants to feature aesthetically pleasing photos of items from library collections on its covers. If you have material in your library's collections that you think would make an attractive CGRL News cover, please send us photographs or color photocopies and a brief description of the items and the collection. Photos may be either color or black-and-white and should be 5" $\times 7^{\prime \prime}$ or $8^{\prime \prime} \times 10^{\prime \prime}$. Illustrations with a vertical orientation work best. Send to: CERL Neu's Covers, 50 E. Huron St., Chicago, IL 60611. 
and codes, and other weather related services. Access: http://www.nws.noaa.gov.

\section{Canada}

Atmospheric Environment Service (Canada). Current weather conditions and forecasts for Canada. Access: http://www.tor.ec. gc.ca/.

\section{More government sites United States}

Environmental Protection Agency. $A C$ cess: http://www.epa.gov/.

U.S. Geological Survey. Access: http: www.usgs.gor

\section{Canada}

Environment Canada. Access: http: www.ec.gc.ca

Natural Resources Canada. Access: http /www.NRCan.gc.ca/

\section{Professional associations}

The Association of American Geographers (AAG). This site includes information on the association, meetings, publications, job postings, and related organizations. Access: http://www.aag.org.

The Canadian Association of Geographers (CAG). This site includes links to the association. its journals, other organizations, and more. Access: http://www.uwindsor.ca/faculty/ socsci/geog/cag/.

Royal Geographical Society /Institute of British Geographers. This site includes information on the society, meetings, publications, and research groups. Access: http: glacier.gg.rhbnc.ac.uk/RHED.html.

\section{Whole publications E-journals}

Geography Resources: Electronic Journals. Part of the University of Texas at Austin Geography site. Links to journals on the Web. Full-text publications are clearly indicated. $A C$ cess: http://www.utexas.edu/depts/grg/ virtdept/resources/journal/journals.htm.

Journal of Geograpbic Information and Decision Analysis (JGIDA). Peer-reviewed, geographic information-based decision analysis. Access: http://www.geog.uwo.ca/gimda/ journal/journal.htm.

Journal of Geography. Full text of the current issue. Access: http://geog.tamu.edu/ journal/main.html.
Transactions of the Institute of Britisb Geographers. Full text of the current issue. Access: http://ppt.geog.qmw.ac.uk/.

\section{Bibliographies}

Population Index. A quarterly bibliography covering all fields of interest to demographers. Includes citations from monographs, journal articles, and other formats. Access: http: /popindex.princeton.edu/.

\section{Newsgroups and discussion lists}

Directory of Scholarly and Professional E-Conferences. Diane K. Kovacs's directory will provide you with a list of mailing lists and newsgroups in geography. Access: http://www. n2h2.com/KOVACS/.

\section{Commercial sites}

Commercial Geography Resources. A basic list of commercial geography sites on the Web. Access: http://www.cla.sc.edu/geog/ geogdocs/otherdocs/comm.html.

GeoPlace.com. Brought to us by the publishers of GIS World, this commercial site is packed with useful information: news, book and software reviews, special columns, and much more. Access: http://www.geoplace.com/.

\section{Other sites}

International Boundaries Research Unit (IBRU). This University of Durham site includes some interesting information on problems associated with international boundaries on land and at sea. In its International Boundaries I)atabase one can type in the name of a place that has had boundary problems and receive a numher of news items on the subject. Access: http: /www-ibru.dur.ac.uk/.

\section{Advertiser index}

$\begin{array}{ll}\text { Britannica Online } & 470 \\ \text { R. R. Bowker } & \text { cover 2, 489 } \\ \text { Brodart Publishing } & 479 \\ \text { Endocrine Society } & 487 \\ \text { EOS International } & 466 \\ \text { Gale Research } & 475 \\ \text { Gaylord Bros. } & 460 \\ \text { Library Corp. } & \text { cover } 3 \\ \text { Merck Pulblishing } & \text { cover } 4 \\ \text { SIRSI } & 457\end{array}$




\section{Surfing is for amateurs.}

Your Web search results: 35 ,
http://worldwide. wait http: http://another. lamesit http://wasted.time http://questionable http://going.nowhere http://questionable http://another.lame http://info-overle.content http://going http://worldwide.wait http://chaos.com h http://another.l wait http://wasted.time. http://questionamesite http://incomplete http://info.overle.content http://info.o http://revisionistoad http://chaos.com ht http://wasted.tint.hist http://worldwide. http://incomplete.net http://deadend.com http://worldwide. net http://questionable http://going.nowhere http://info-overloa http://deadend.core http://revisionist.h :lamother. late ew the next l, 1000 sites?

\section{Don't wipe out. Use GaleNet.}

If the Web isn't giving your patrons the targeted answers they need, look into GaleNet.

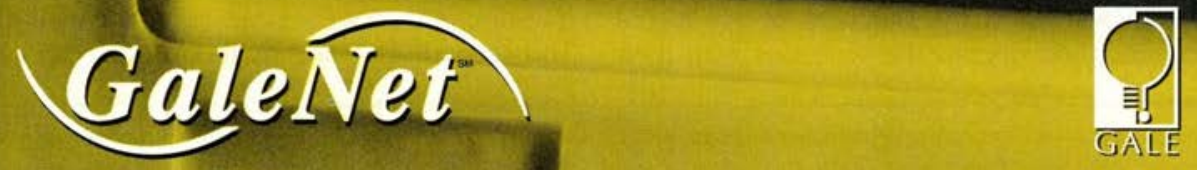

TRY GALE'S ONLINE SUBSCRIPTION SERVICE TODAY free demo at www.gate,com - 1-800-877-GALE 